\begin{tabular}{|l|l|}
\hline JURNAL ABDI MASYA & Volume 1 No 2 \\
Mei 2021 \\
E-ISSN : 2774-2849 & Pp 83-91 \\
P-ISSN : 2774-2881 & Website : https://jurnal.sttw.ac.id/index.php/abma/about \\
\hline
\end{tabular}

\title{
Pelatihan Dasar Gambar Teknik Dengan Perangkat Lunak CAD Dalam Proses Perancangan
}

\section{BASIC TRAINING OF TECHNICAL DRAWING USING CAD SOFTWARE IN THE DESIGN PROCESS}

\author{
Sukmaji Indro Cahyono ${ }^{1^{*}}$, Triyono ${ }^{2}$ \\ ${ }^{1,2}$ Program Studi Teknik Mesin, Fakultas Teknik, Universitas Sebelas Maret, Surakarta \\ *E-mail : sukmaji@ft.uns.ac.id
}

\begin{abstract}
ABSTRAK
Usaha bengkel las di Wilayah Jaten Karanganyar sebagian besar mengerjakan kontruksi kecil hingga sedang dan belum mampu mendapatkan proyek besar. Permasalahan utama yang dihadapi adalah desain yang diinginkan konsumen hanya dibuat sket gambar manual seadanya tanpa mengukuti kaidah gambar teknik standar ISO dan tanpa melalui proses perancangan, sehingga estimasi biaya dan kebutuhan bahan hanya perkiraan saja dengan kata lain tidak standar. Selain itu dalam proses pembuatan produk, terjadi banyak kesalahan pengukuran sehingga pemotongan dan penggunaan bahan tidak effesien. Tujuan menjadi fokus utama PKM ini adalah pengenalan proses perancangan, pelatihan dan pendampingan penggunaan perangkat lunak CAD dalam mendesain dan merancang produk yang dikerjakan dengan proses pengelasan. Mitra utama program pengabdian ini adalah juru las dan warga sekitar terutama warga lulusan sekolah vokasi/SMK untuk berkolaborasi dengan mengangkat studi kasus merancang dan mendesain pembuatan Gazebo masjid Fatimah ArRoyyan Jaten karanganyar. Metode yang dipilih pada proses pengabdian demi tercapainya tujuan pengabdian adalah kolaborasi interaktif, yang dibantu dengan media animasi manufaktur dan detail gambar Teknik standar ISO. Hasil dari kegiatan pengabdian ini adalah tumbuhnya minat warga yang ingin mempelajari dan menguasai pengoperasian perangkat lunak desain CAD. Evaluasi secara keseluruhan terjadi peningkatan interaksi antara mitra pembuat (juru las dengan Mitra konsumen) dengan adanya peresentasi visual gambar 3D maupun gambar teknik, dan terjadi efesiensi penggunaan bahan dan proses yang lebih baik sehingga keuntungan proses jasa manufaktur proses las meningkat.
\end{abstract}

Kata Kunci : Perancangan, Desain CAD, Manufaktur Las, Gambar Teknik.

\begin{abstract}
Most of the welding workshops in the Jaten Karanganyar area work on small to medium construction projects and have not been able to secure large projects. The main problem faced is that the design that consumers want is only a simple manual drawing sketch without following ISO standard technical drawing rules and without going through the design process, so that the estimated cost and material requirements are only estimates, in other words not standardized. In addition, in the product manufacturing process, there are many measurement errors so that cutting and using materials are not efficient. The aim of being the main focus of this PKM is the introduction of the design process, training, and assistance in the use of CAD software in designing and designing products that are done by the welding process. The main partners of this service program are welders and residents, especially residents of vocational school / vocational school graduates, to collaborate with case studies of designing and designing the making of the Fatimah Ar-Royyan Jaten Jaten mosque Gazebo. The method chosen in the service process to achieve the goal of service is interactive collaboration, which was assisted by manufacturing animation media and detailed ISO standard engineering drawings. The result of this service activity is the growing interest of residents who want to learn and master the operation of CAD design software. Overall evaluation there is an increase in interaction between manufacturing partners (welders and consumer partners) with the visual presentation of $3 D$ images and technical drawings, and better efficiency in the use of materials and processes so that the advantages of the welding process manufacturing service process increase.
\end{abstract}




\section{Submit: 15 April 2021, Accepted: 28 April 2021 Published: 28 Mei 2021}

\section{PENDAHULUAN}

Hasil pengamatan dan analisis situasi kondisi obyektif UKM Bengkel Las Desa Jaten karanganyar hingga saat ini, segmen pasar pada usaha bengkel las di Wilayah Jaten tergolong sama yaitu produk yang digunakan pada sektor perumahan, seperti pagar, teralis pintu, tangga dan lain-lain, oleh karena varian produk yang sedikit, maka bengkel las tersebut kadang kebanjiran order tapi di lain waktu sepi dari order. Persaingan usaha sangat ketat karena jumlah bengkel las yang sangat banyak sedangkan jumlah konsumen terbatas. Lihat Gambar 1. Proses pendampingan wirausaha/UKM dalam program PKM.

Permasalahan utama yang di alami mitra bengkel las tersebut sebagian besar mengerjakan kontruksi tanpa menggunakan gambar kerja/gambar teknik. Gambar yang diinginkan konsumen hanya dibuat sket gambar manual seadanya tanpa mengukuti kaidah standar gambar teknik.

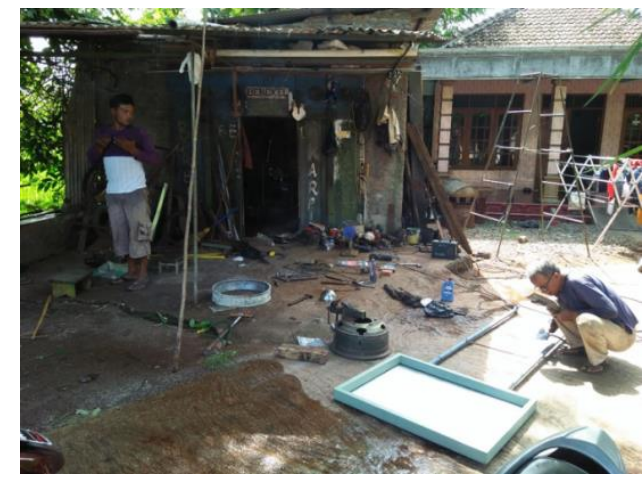

Gambar 1. Kondisi dan situasi Bengkel Las Sumber Rejeki yang berada di Dusun Sawahan Desa Jaten

Selain itu, keahlian juru las tersebut bisa mengerjakan pekerjaan pengelasan dengan belajar secara otodikdak sehingga mempunyai beberapa kelemahan antara lain:

a) Pengetahuan merancang desain yang hanya mengikuti gambar maupun contoh yang telah ada di pasaran/digunakan masyarakat.

b) Tidak memiliki keahlian Gambar teknik maupun pengoperasian perangkat lunak gambar CAD mumpuni yang menjelaskan kebutuhan material dan bentuk desain secara rinci.

c) Pengetahuan juru las tentang perancangan manufaktur las kurang.

d) Effisiensi penggunaan material dan akurasi pengukuran yang rendah.

Maka dari deskripsi di atas permasalahan mitra PKM yaitu bengkel las Sumber Rejeki Dusun Sawahan, Jaten, Karanganyar dapat didefinisikan. Oleh karena itu, solusi yang dijalankan oleh tim PKM UNS adalah sebagai berikut:

Pertama, memberi contoh alur proses standar menggunakan gambar teknik standar ISO. Membuat alur gambar kerja dari desain hingga proses pengelasan. Dalam membuat produk percontohan adalah desain Gazebo dengan yang memiliki 3 ukuran. Gambar teknik tersebut memiliki detail proses dan ukuran hingga kebutuhan material. Proses pengembangan desain pada program pengabdian masyarakat memerlukan gambar teknik [1] 
Kedua, memberikan pelatihan pengenalan menggambar teknik menggunakan perangkat lunak CAD. Memberikan pelatihan penggunaan gambar teknik dalam aplikasi desain untuk pengelasan. Proses dimulai dari sket atau gambar contoh yang diinginkan konsumen, lalu digambar menngunakan software 3D, pendetailan perpart/komponen dengan modul-modul assembling, lalu dilanjutkan pembuatan gambar teknik 2D standar ISO berikut animasi cara assembling yang disarankan. Pelatihan penggunaan perangkat lunak dalam program PKM dilakukan oleh [2], sedangkan perangkat lunak untuk tujuan pendidikan dilakukan oleh [3], [4].

Ketiga, memberi penjelasan dan pemahaman tentang gambar kerja teknik pengelasan. Memberikan masukan dan penjelasan secara interaktif bagainama perubahan desain terhadappenyesuaian keinginn konsumen dan penyederhanaan berikut pembacaan posisi gambar dan keterangan tambahan mengenai proses manufaktur Gazebo.

Estimasi target yang akan menjadi luaran dari pelaksanaan PKM ini adalah meningkatnya jumlah juru las maupun warga yang memiliki minat keahlian desain dan gambar teknik standar ISO menggunakan perangkat lunak CAD. Dengan modal tersebut diharapkan dimasa yang akan datang para juru las yakin dan percaya diri untuk dapat mengambil proyek-proyek skala yang lebih besar dibidang pengelasan dan mampu bersaing dengan profesi sejenis dari daerah lain. Selain itu, bentuk luaran lainnya adalah tersusunnya materi pelatihan dan pembelajaran berupa gambar 3D dan gambar Teknik dengan studi kasus perancangan desain gazebo. Luaran selanjutnya adalah terwujudnya produk teknologi yang jadi percontohan alur desain-perancangan hingga manufaktur, Gazebo ukuran 3 x 5, 3 x 3 dan 2,5 x 2,5meter yang digunakan untuk aktifitas masjid dan masyarakat pada umumnya. Proses serupa juga diterapkan dalam rancang bangun mesin yang dilakukan oleh [5]. Deskripsi Proses Kegiatan Pengabdian PKM UNS diuraikah dalam tiga tahap berikut:

Tahap I adalah Pembuatan materi contoh desain gazebo yang telah dikonversi menjadi gambar teknik setandar ISO. Proses tersebut dikemas perlangkah yang kemudian dijadikan materi pelatihan pada tahap 2. Proses sket dan pemilihan desain merupakan kesepakatan takmir dan jamaah masjid yang disesuaikan dengan kondisi lahan yang akan dijadikan tempat didirikan gazebo.

Tahap II adalah Pelatihan dan pengenalan gambar teknik yang membantu dalam proses las pada pembuatan gazebo. Terjadi perubahan rencara pada tahap ini dimana pada rencana awal tahap ini adalah pelatihan menggunakan software CAD. Namun karena kondisi fasilitas komputer dan latarbelakang keahlian yang berbeda-beda sehingga pelatihan tidak dimungkinkan hanya sekali pertemuan sehingga pada tahap ini di selenggarakan Pengenalan penggunaan software CAD yang diharapkan tumbuh minat dikalangan warga dan bila fasilitas komputer telah tersedia akan dilanjutkan kegiatan pelatihan yang mendatangkan tutor dari tenaga pengajar Teknik Mesin UNS.

Tahap III adalah praktek pelatihan las dengan membuat tiga macam Gazebo di depan masjid Fatimah Ar-Royyan Jongkang dengan dana pendamping dari mitra ke 3 yaitu Takmir Masjid Fatimah Ar-Royyan. Gazebo tersebut memiliki ukuran; gazebo besar 5x3 mete, gazebo sedang $3 \times 3$ meter dan Gazebo Kecil 2.5 x2.5 meter, yang telah didesain oleh Tim PKM UNS dengan melibatkan juru las yang telah disertifikasi untuk semakin memantapkan pemahaman tentang Gambar Teknik. Rangkuman tahapan pelaksanaan dapat dilihat pada Gambar 2. 


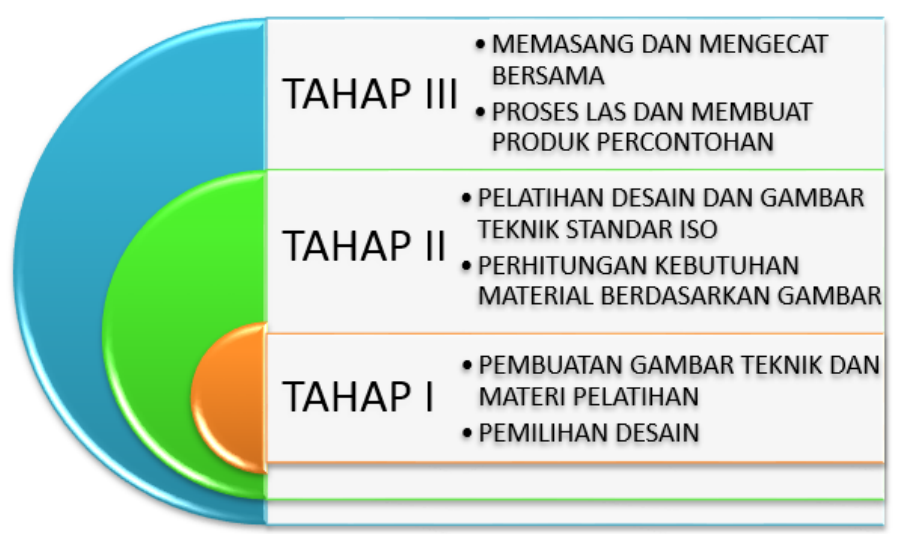

Gambar 2. Tahapan dalam pelaksanaan pengabdian kepada masyarakat.

\section{PELAKSANAAN DAN METODE}

Proses perancangan hingga pembuatan pada pengabdian ini menggunakan metode kolaborasi interaktif. Pembuatan materi pelatihan ini dilakukan oleh tim PKM UNS di kampus Teknik Mesin yang mengemas materi pelatihan secara interaktif dengan alur perancangan dan desain agar mudah dimengerti oleh Mitra. Berdasarkan teori gambar teknik, representasi desain visual pada Gambar 3, dalam mendesain hingga produk jadi memerlukan paling sedikit 4 langkah, diantaranya; a) terbentuknya gambar sket, b) terbentuknya gambar 3D/2D, c) terbentuknya model terpilih, dan terakhir d) pembuatan prototipe. Sedangkan metode perancangan yang dipilih adalah reverse engineering atau merancang ulang dengan desain yang sudah ada kemudian di sempurnakan dengan analisa keteknikan.

Proses perancangan pembuatan desain dengan contoh kasus gazebo masjid dimulai dengan mencari contoh desain, yang kemudian dibuat gambar sket. Dengan metode reverse engineering yang mana suatu produk baru dibuat dengan cara menggambar ulang produk lama setelah dilakukan efesiensi dan penyempurnaan. Gambar sket ini menjadi panduan dalam membuat model gambar 3D produk gazebo yang baru. Gambar sket ini merupakan kesepakatan yang telah disetujui konsumen dalam kasus ini adalah jamah dan takmir dan disesuaikan dengan kondisi luas lahan. Lihat Gambar 4.

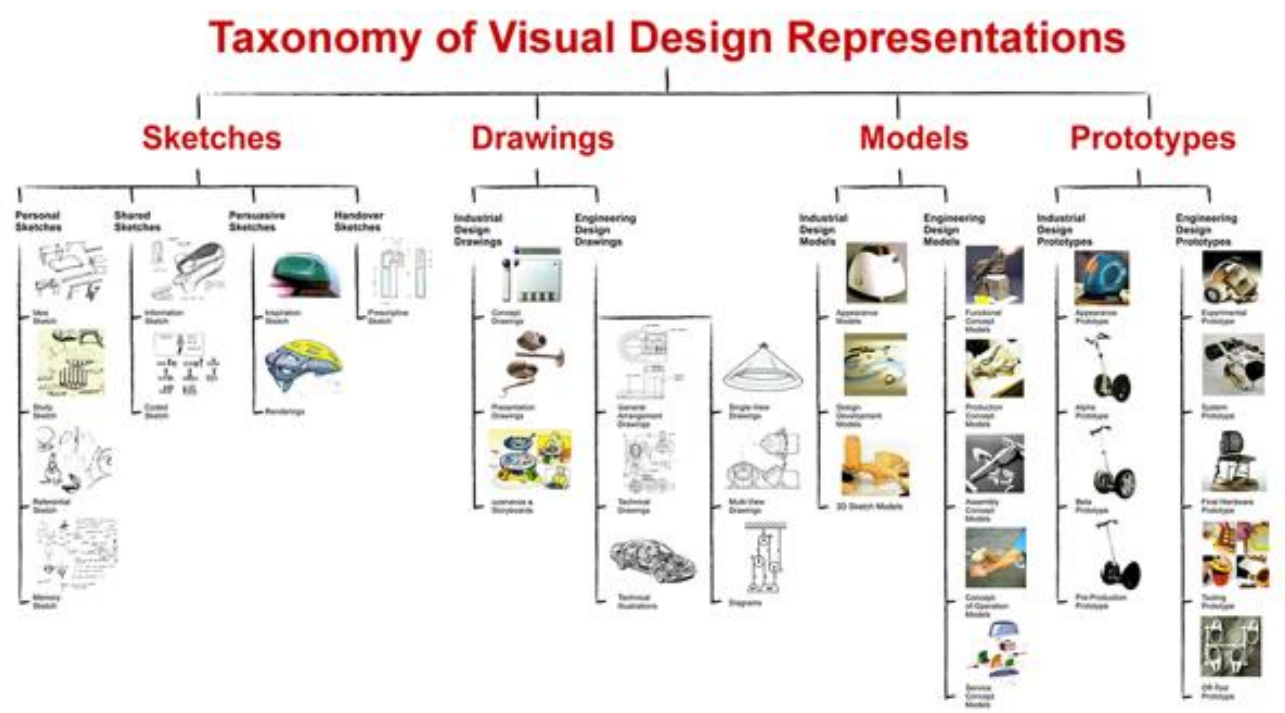

Gambar 3. Taksonomi representasi desain visual [6] 
Proses perencanaan Gambar Gazebo ini mengikuti proses perencaaan rangka kudakuda pada pembangunan yang dilakukan oleh Harisun (2020) [7]

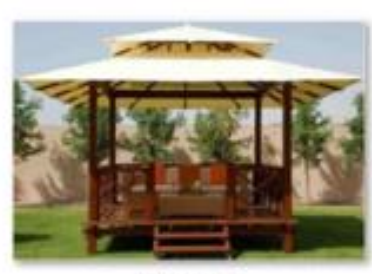

GK $2.5 \times 2.5$

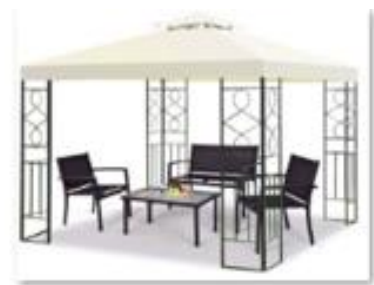

$\operatorname{GS} 3 \times 3$

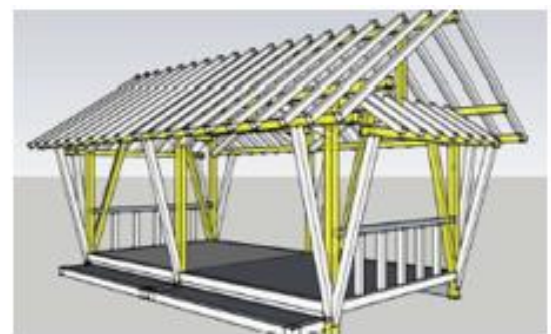

Gambar 4. Gambar sket yang menjadi acuan desain 3 buah model gazebo dengan metode reverse engineering.

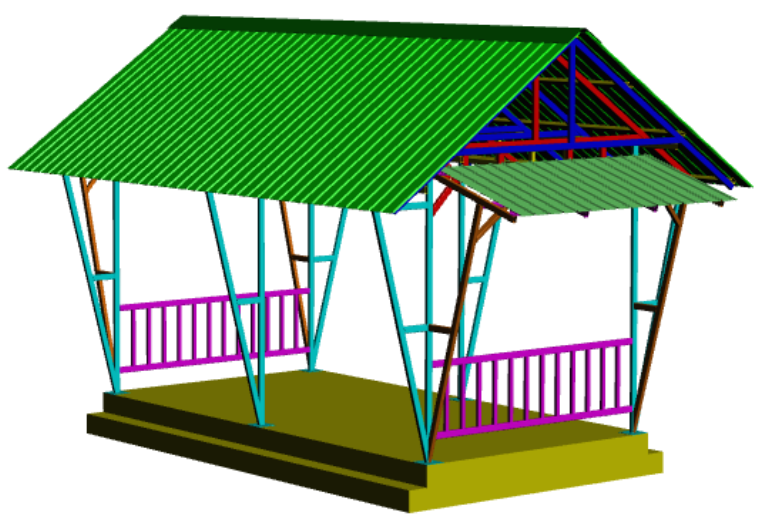

Gambar 5. Gambar sket yang menjadi acuan desain 3 buah model gazebo dengan metode reverse engineering

Gambar 5 adalah gambar 3D gazebo yang dihasilkan software CAD yang telah jadi kemudian dikonsultasikan dengan Mitral pengguna dan Mitra 2 yaitu dari juru las. Beberapa perubahan terjadi terkait proses penyambungan frame menjadi modul-modul untuk memudahkan pemindahan dari bengkel las ke tempat pemasangan.
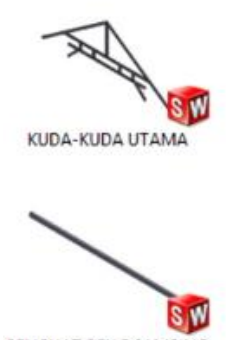

PENGUAT RENG SAMPING

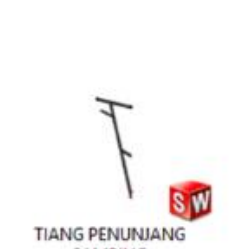
TIANG PENUNJANG
SAMPING

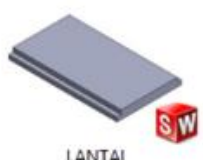

LANTAI

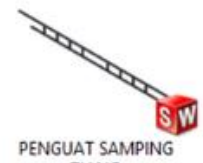

TIANG
TENGUT SAMPINC

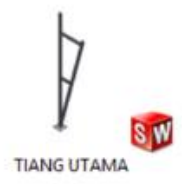

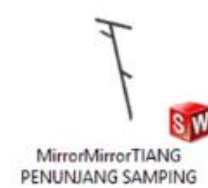
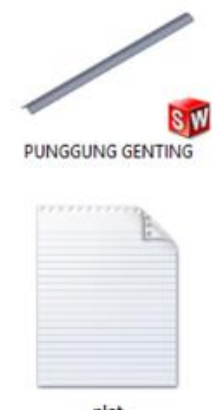

plot

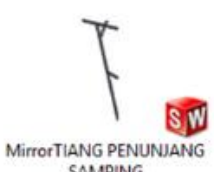

SAMPING

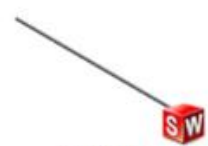

RENG ATAS

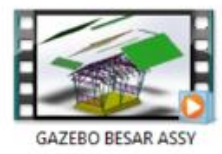

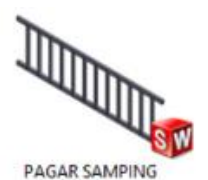

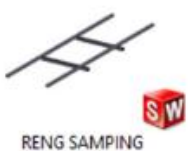

RENG SAMPING

Gambar 6. Gambar 3D dipecah perkomponen dengan pengelompokan modul-modul untuk memudahkan pemindahan ke tempat pemasangan gazebo. 
Proses pemecahan gambar 3D menjadi komponen-komponen modul seperti yang terlilhat pada gambar 6 ini, dibuat pula video animasi tahapan pemasangan yang diharapkan pembuat maupun pemasang tanpa keahlian sekalipun dapat memahami setiap langkah pembuatan dengan baik. Pembuatan video dalam penyampaian informasi lebih baik dari pada menggunakan deskripsi tertulis dan gambar [8] dan [9].

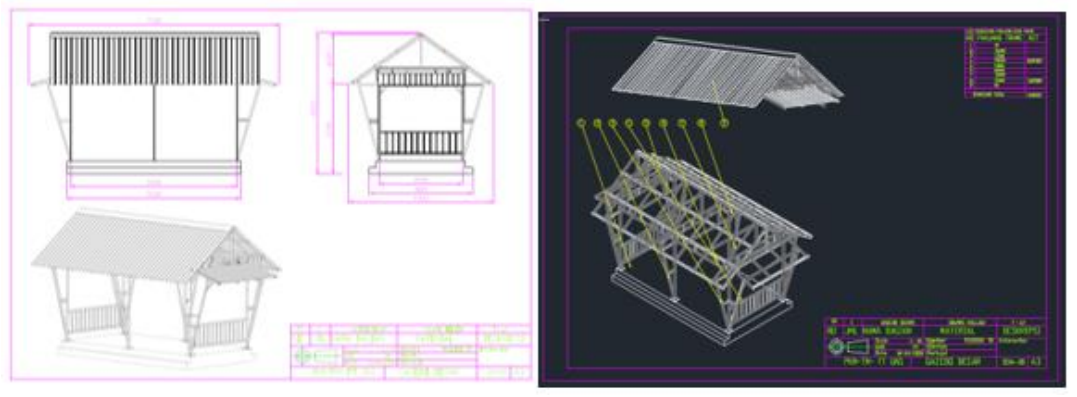

Gambar 7. Gambar 3D dikonversi menjadi gambar 2D dan diberi ukuran beserta atribut teknik

Proses selanjutnya mengkonversi seluruh gambar 3D menjadi gambar 2D sehingga memudahkan dalam perincian ukuran dan penamaan komponen. Lihat Gambar 7 di atas.

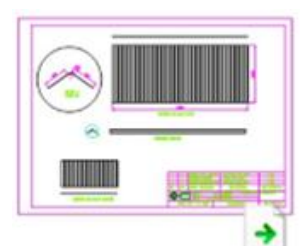

GENTING GALVALU ISO

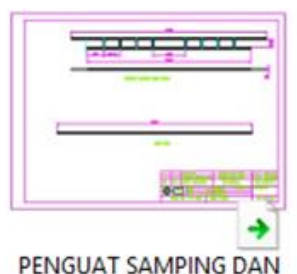$$
\text { RFNG }
$$

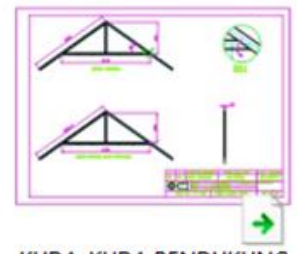

KUDA-KUDA PENDUKUNG

ISO

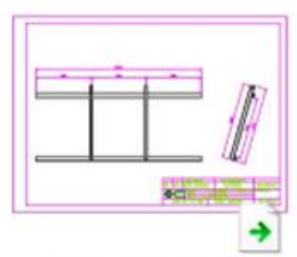

RENG SAMPING ISO
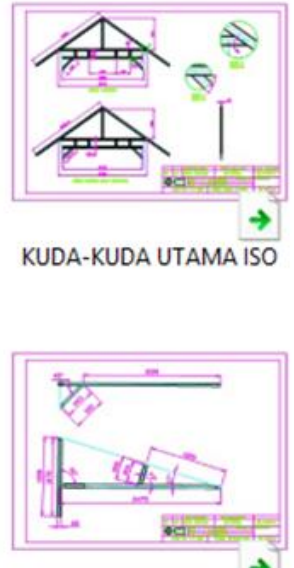

TIANG PENUNJANG ISO

Gambar 8. Seluruh gambar komponen 3D dikonversi menjadi gambar 2D dan diberi ukuran detail mengikuti kaidah standar ISO.

Gambar yang telah dikonversi menjadi 2D diberi ukuran mengikuti kaidah standar ISO, sehingga secara rinci dapat dipahami dan dibuat juga kebutuhan panjang frame. Perkiraan biaya yang dibutuhkan dapat diperkirakan dengan baik. Hasil perhitungan dan biaya yang dibutuhkan sangat mahal sehingga beberapa frame dikurangi dan beberapa frame ukurannnya diperkecil untuk menghemat biaya pembuatan. Namun berdasarkan perhitungan dan simulasi komputer tetap konstruksi gazebo berada di atas batas faktor keamanan konstruksi yang diizinkan. Lihat Gambar 8. 


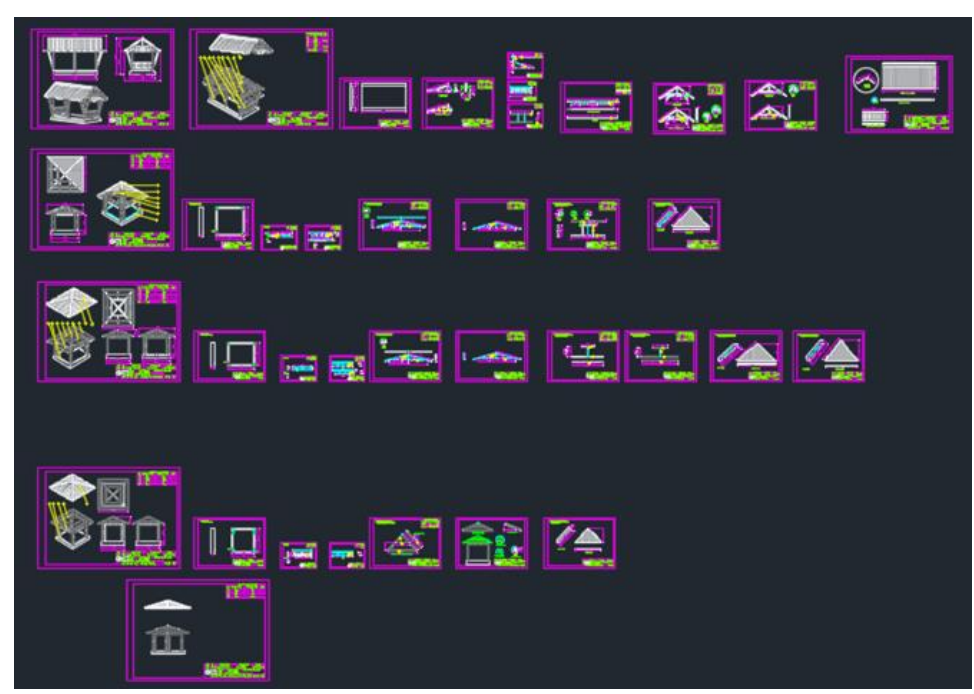

Gambar 9. Seluruh model gazebo dibuat dengan alur proses yang sama dan berkesinambungan.

Pada tahap akhir perubahan yang dibuat disesuaikan dan perhitungan BOM (bill of material) atau biasa disebut gambar untuk memprediksi kebutuhan material sehingga perkiraan biaya dapat lebih dihemat dan lebih akurat dibanding hanya perkiraan saja. Lihat Gambar 9.

Pelatihan pada tahap awal dengan jumlah peserta 22 orang kurang optimal karena adanya wabah covid, namun minat peserta cukup tinggi, hal ini dapat terlihat dari banyaknya pertanyaan dan keinginan untuk menguasai pengoperasian perangkat lunak CAD. Waktu yang dibutuhkan untuk pelatihan membutuhkan waktu 8 kali pertemuan, karena munculnya wabah covid selanjutnya pelatihan direncanakan dilakukan secara daring/online. Lihat Gambar 10.

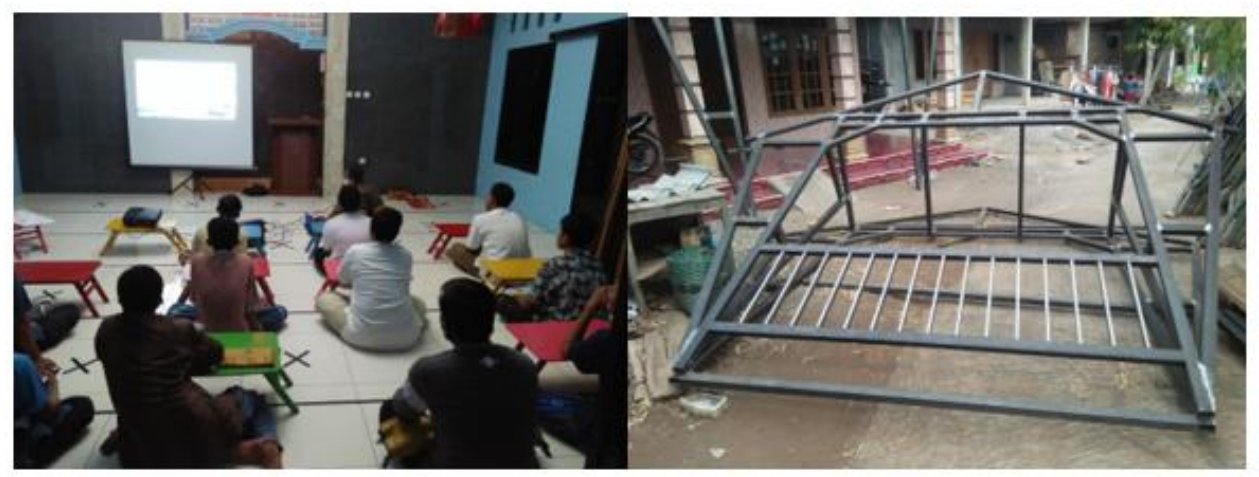

(a)

(b)

Gambar 10. (a) Pelatihan pengenalan gambar teknik dan software CAD dalam pembuatan Gazebo. (b) Proses pembuatan oleh juru las.

\section{HASIL DAN PEMBAHASAN}

Hasil Kegiatan pengabdian kepada masyarakat yaitu Mitra ke-tiga Masjid Fatima ArRoyan menjadi penerima produk hasil kegiatan pelatihan juru las berupa Gazebo. Sedangkan mitra kedua yaitu juru las dan warga lulusan sekolah vokasi/SMK yang mempelajari mendapat ilmu dan pengalaman dalam mendesain dan pembuatan gambar teknik standar ISO yang diajarkan meskipun wabah covid cukup berdampak besar dalam kegiatan pengabdian. Lihat Gambar 11. 
Evaluasi desain yang diharapkan sesuai dengan keinginan konsumen. Hanya beberapa bagian yang perlu dikurangi karena terjadi overdesign (material yang dipilih terlalu besar). Perhitungan struktur Gazebo menggunakan simulasi CFD dapat mampu bertahan dari angin kencang di area persawahan dengan kecepatan maksimal mencapai 76 $\mathrm{km} / \mathrm{jam}$ dan dari estimasi awal struktur mampu menahan beban manusia yang sedang memasang atap Galvalum. Secara umum struktur tergolong aman.

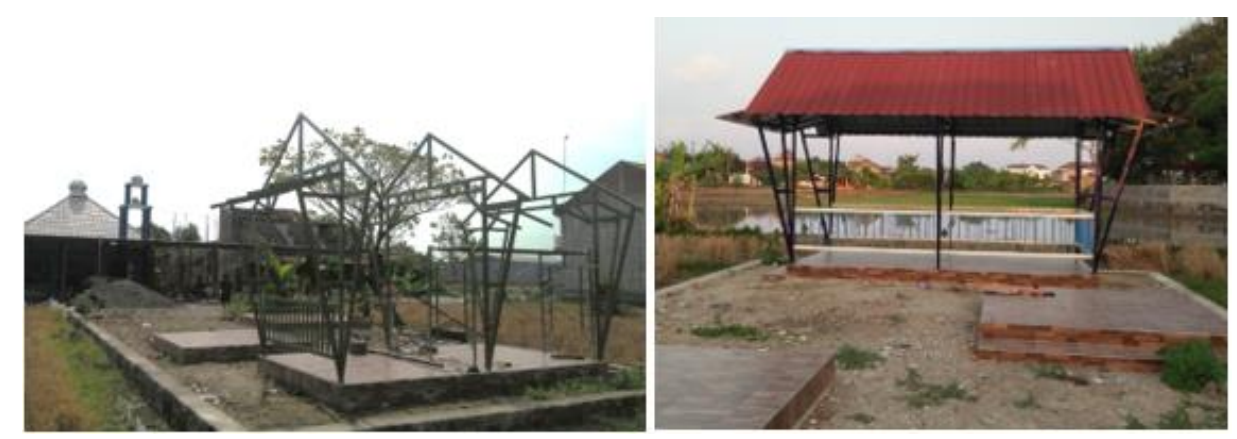

Gambar 11. Pemasangan produk hasil desain menggunakan program CAD berupa Gazebo di Masjid Fatima Ar-Royan.

Estimasi awal juru las memperkirakan proses manufaktur pengelasan Gazebo tanpa bantuan Gambar Teknik akan memakan waktu 2 minggu. Setelah diberikan pelatihan dan gambar Teknik, satu unit Gazebo dapat selesai selama 5 Hari. Estimasi biaya dengan menggunakan Gambar Teknik tidak banyak berubah antara rencana dan pelaksanaan, namun efesiensi penggunaan bahan meningkat, hal ini dapat dilihat dari sisa bahan tidak terpakai yang sangat sedikit.

\section{PENUTUP}

Dalam Ilmu Perancangan teknik, mitra yang bergerak dibidang pengelasan membutuhkan keahlian di bidang perencanaan. Selama ini proses perencanaan dan desain hanya tergantung pada insting dan coba-coba. Perencanaan juga tergantung kepada pesanan dan belum dihitung faktor keamanan dan kebutuhan materialnya. Terkadang hal itu berdasarkan pengalaman di tempat lain maupun desain yang dibuat sangat aman sehingga banyak material sia-sia menjadi lebih tebal maupun berat. Penggunaan perangkat lunak CAD sangat membantu dalam proses perancangan dan estimasi biaya yang akurat. Progres selama kegiatan berlangsung cukup baik, perlu ditingkatkan pelatihan intensif menggambar dengan bantuan software CAD dan pemahaman pembuatan ukuran sesuai standar ISO.

Keahlian peserta dalam menguasai materi perancangan tersebut membutuhkan minimal pengalaman di bidang Teknik seperti Sekolah Vokasi atau SMK. Selain itu fasilitas Penunjang seperti seperangkat komputer sangat dibutuhkan, dan lisensi legal perangkat lunak CAD seperti Autocad maupun Solidwork yang dimiliki Universitas perlu dibuka untuk kepentingan pengabdian masnyarakat seperti ini maupun penelitian.

\section{UCAPAN TERIMA KASIH}

Kegiatan pengabdian ini telah didanai oleh program P2M LPPM UNS di bawah naungan Kementrian Riset, Teknologi dan Pendidikan Tinggi Repubik Indonesia 


\section{DAFTAR PUSTAKA}

[1] B. Binyamin, M. N. Asnan, B. B. Prasetyo, and D. F. Ledau, "Program Pelatihan Gambar Teknik Menggunakan Aplikasi AutoCAD di SMK Muhammadiyah 3 Samarinda," J. Pesut Pengabdi. untuk Kesejaht. Umat, vol. 2, no. 1, pp. 52-61, 2020.

[2] S. Shedriko, H. S. Setiawan, and K. Kusmayadi, "Pelatihan Perangkat Lunak Powerpoint untuk Meningkatkan Kinerja Guru di SD dan SMP 19 Muhammadiyah Sawangan Depok," J. PkM Pengabdi. Kpd. Masy., vol. 1, no. 02, pp. 151-158, 2018.

[3] R. Rais, I. Afriliana, and E. Budihartono, "Peningkatan Ketrampilan Multimedia CorelDraw Di SMK Assalafiyah kota Tegal," J. Abdimas PHB J. Pengabdi. Masy. Progresif Humanis Brainstorming, vol. 1, no. 1, pp. 55-61, 2017.

[4] L. Angriani and A. R. Dayat, "PKM Peningkatan kompetensi guru dan siswa melalui pelatihan pemrograman dan jaringan komputer pada sekolah menengah kejuruan di Kota Jayapura," J. Abdimas, vol. 23, no. 2, pp. 92-98, 2019.

[5] S. Sugiyanto and J. Trisnowati, "Rancang Bangun Mesin Perajang Kerupuk Jengkol untuk Meningkatkan Pendapatan UKM," J. Engine Energi, Manufaktur, dan Mater., vol. 2, no. 2, pp. 25-30, 2018.

[6] E. Pei, I. Campbell, and M. Evans, "A taxonomic classification of visual design representations used by industrial designers and engineering designers," Des. J., vol. 14, no. 1, pp. 64-91, 2011.

[7] E. Harisun, "SOSIALISASI DAMPAK KERUSAKAN RUMAH PASCA GEMPA DI DESA TAWA," J. Pengamas, vol. 3, no. 1, pp. 22-30, 2020.

[8] U. Pudjianto, A. K. Adisusilo, L. Retnawati, and N. Saurina, "PENINGKATAN KOMPETENSI TENAGA PENDIDIK MUSLIMAT NU SURABAYA DALAM PENGUASAAN TEKNOLOGI INFORMASI DAN KOMUNIKASI (TIK)," Adimas J. Pengabdi. Kpd. Masy., vol. 4, no. 1, pp. 22-28, 2020.

[9] Z. Apriliani, U. Hasanah, and A. S. Anas, "Pembuatan Video Profil dengan Efek Vintage Kampung Wisata Adat Sengkoah sebagai Media Informasi," JTIM J. Teknol. Inf. dan Multimed., vol. 1, no. 1, pp. 57-65, 2019. 